\title{
NETOLYGUS GEOGRAFINIS GYDYTOJŲ PASISKIRSTYMAS: SISTEMINĖ KITŲ ŠALIŲ PATIRTIES APŽVALGA
}

\author{
Liudvika Starkienè \\ Lietuvos sveikatos mokslų universiteto \\ Medicinos akademijos Visuomenès sveikatos fakulteto \\ Profilaktinès medicinos katedra \\ Eivenių g. 4, LT-50161 Kaunas, Lietuva \\ Telefonas (+370 6) 1149215
}

Elektroninis paštas: liudvika.starkiene@lsmuni.lt; liudvika.starkiene@gmail.com Pateikta 2013 m. liepos 5 d., parengta spausdinti 2013 m. rugsejjo 17 d.

doi:10.13165/SPV-13-1-5-07

\section{Santrauka}

Pusè visu pasaulio gyventoju gyvena kaimo vietovèse, tuo tarpu jose dirba mažiau nei ketvirtadalis pasaulio gydytojų. Sistemine literatūros šaltinių paieška, atrenkant kitose šalyse vykdytas netolygiam gydytoju pasiskirstymui spręsti skirtas programas, buvo atlikta pagal šiuos kriterijus: ieškota tik gydytojams skirtas veikiančias programas aprašančių visateksčiu straipsnių, paskelbtu 2000-2013 m. anglu kalba, naudojant PubMed duomenu bazés paieškos sistema. Nustatytus kriterijus atitiko 18 straipsniu, kuriuose aprašoma 14 gydytoju pritraukimo ir išlaikymo geografiškai nepatraukliose vietovése programų. Nustatyta, jog programos, kuriose taikomos tik finansinés paskatos, dažniausiai pasiteisina, pritraukiant gydytojus i geografiškai nepatrauklias vietoves ir išlaikant juos ten trumpa laikotarpi (2-6 m.). Užsieniečiu gydytoju idarbinimo programos taip pat nera ilgalaikis sprendimas, kadangi jis veiksmingas iki sutarties galiojimo pabaigos. Medicinos studentu rengimo darbui geografiškai nepatraukliose vietovése programos (tiek su stipendija ir isipareigojimais, tiek be ju), nors ir nepadeda greitai išspręsti gydytojų trūkumo problemos, tačiau yra labai naudingos ilguoju laikotarpiu.

Reikšminiai žodžiai: gydytojai, netolygus geografinis pasiskirstymas, pritraukimo ir išlaikymo programos, sveikatos politika.

\section{Ivadas}

Su netolygaus geografinio gydytojų pasiskirstymo problema susiduria visos šalys, nors problemos mastas, kaip ir bandymai ją spręsti, yra skirtingi. Netolygų geografinị pasiskirstymą galima apibrèžti kaip aprūpinimo gydytojais skirtumus, neigiamai veikiančius sveikatos priežiūros sistemos funkcionavimą, reikiamų sveikatos priežiūros paslaugų prieinamumą 
bei jų kokybę, pacientų pasitenkinimą ir prasčiau gydytojais aprūpintų vietovių gyventojų sveikatos rodiklius ${ }^{1,2}$.

Šiame straipsnyje aprašant gydytojų pritraukimo ir išlaikymo programas, vartojamas terminas „geografiškai nepatrauklios vietovès“, apimantis visas kaimų, rajonų, atokias, nutolusias ir pan. vietoves, kuriose susiduriama su gydytojų stygiumi.

Pasaulio sveikatos organizacijos duomenimis, pusė visų pasaulio gyventojų gyvena kaimo vietovèse, tuo tarpu jose dirba mažiau nei ketvirtadalis pasaulio gydytojų ${ }^{3}$. Istoriškai susiklostè, kad gydytojai yra labiau linkę apsigyventi ir verstis medicinos praktika miestuose, kur yra geresnès darbo ir profesinio tobulëjimo galimybės, ugdymo ir kitos socialinès sąlygos, kurios svarbios ne tik jiems patiems, bet ir jų šeimų nariams ${ }^{4}$. Jungtinėse Amerikos Valstijose geografiškai nepatraukliose vietovėse dirbo mažiau nei 11 proc. gydytojų, o Kanadoje - 9 proc., tuo tarpu jose gyveno atitinkamai 20 ir 24 proc. visų gyventojų ${ }^{5}$. Indijoje geografiškai nepatraukliose vietovėse dirbo 26 proc. gydytojų, tačiau jose gyveno net 72 proc. visų šalies gyventojų ${ }^{6}$. Lietuvoje $2012 \mathrm{~m}$. rajonuose dirbo 28,4 proc. gydytojų, o juose gyveno 33,2 proc. gyventojų ${ }^{7},{ }^{8}$.

Gydytojų apsisprendimą dirbti geografiškai nepatraukliose vietovėse lemia asmeniniai veiksniai (kilimas iš šių vietovių, vertybès, altruizmas), šeimos ir bendruomenès veiksniai (šeimos narių ịsidarbinimo ir ugdymo galimybès (darželių ir mokyklų buvimas), vietinès bendruomenès charakteristikos), finansiniai ir ekonominiai veiksniai (darbo užmokestis ir ịvairūs priedai), su profesine karjera susiję veiksniai (tęstinio profesinio tobulèjimo galimybės, profesinis palaikymas, galimybė eiti vadovaujančias pareigas), darbo ir gyvenimo sąlygos (darbovietès infrastruktūra, darbo krūvis, apgyvendinimo sąlygos), taip pat privalomas tam tikros trukmės vertimasis medicinos praktika (mainais ị gautą stipendiją ar privalomas paskyrimas visiems absolventams $)^{9},{ }^{10},{ }^{11}$.

Dažniau medicinos praktiką geografiškai nepatraukliose vietovèse renkasi vyrai, kilę iš tokių vietovių ir jau stodami ị medicinos studijas apsisprendę, jog grịš dirbti ị savo kilmès ar kitą geografiškai nepatrauklią vietovę. Tokị apsisprendimą taip pat lemia ir pasirinkta šei-

1 Blumenthal, D. Geographic imbalances of physician supply: an international comparison. Journal of Rural Health. 1994, 10(2): 109-118.

2 Humphreys, J.; Solarsh, G. At-rist populations: rural. Heggenhougen HK, ed. The International Encyclopedia of Public Health. London: Elsevier, 2008, 242-253.

3 World Health Organization. World Health Report 2006: Working together for health. 2006.

4 Gupta, N., et al. Uses of population census data for monitoring geographical imbalance in the health workforce: snapshots from three developing countries. Int J Equity Health. 2003, 2(1): 11.

5 Dumont, J. C., et al. International mobility of health professionals and health workforce management in Canada: myths and realities. OECD Health working paper no 40. Paris: OECD, 2008.

6 Sundararaman, T.; Gupta, G. Indian approaches to retaining skilled health workers in rural areas. Bull World Health Organ. 2011, 89(1): 73-77.

7 Lietuvos gyventoju sveikata ir sveikatos priežiūros istaigu veikla $2012 \mathrm{~m}$. (išankstiniai duomenys). Vilnius: Higienos instituto Sveikatos informacijos centras, 2013, p. 73-75.

8 Lietuvos statistikos departamentas. Oficialiosios statistikos portalas [žiūrèta 2013-04-23]. <http://osp. stat.gov.lt $>$.

9 Dussault, G.; Franceschini M. Not enough there, too many here: understanding geographical imbalances in the distribution of the health workforce. Human Resources for Health. 2006, 4: 12.

10 Buykx, P.; Humphreys, J.; Wakerman, J.; Pashen, D. Systematic review of effective retention incentives for health workers in rural and remote areas: towardsevidence-based policy. Aust J. Rural Health. 2010, (3): 102-109.

11 Wibulpolprasert, S.; Pengpaibon, P. Integrated strategies to tackle the inequitable distribution of doctors in Thailand: four decades of experience. Hum Resour Health. 2003, 1(1): 12. 
mos, bendruomenès ar kaimo medicinos rezidentūros studijų programa. Teigiamą poveikị (tik silpnesnị) taip pat turi ilgesnès trukmès klinikinè praktika studijų metu geografiškai nepatraukliose vietovèse. Autoriai taip pat pastebi, kad užsieniečių įdarbinimas šiose vietovėse, stipendijų skyrimas mainais už darbą ir finansinio skatinimo priemonès taip pat prisideda prie netolygaus geografinio pasiskirstymo problemos sprendimo ${ }^{12},{ }^{13}$.

Gydytojų pasiūlos ir poreikio analizè ir planavimas bei tolygaus geografinio jų pasiskirstymo užtikrinimas yra svarbi sveikatos politikos dalis, kuriai, deja, Lietuvoje nebuvo skiriamas pakankamai dèmesio. Nebuvo net mėginama parengti valstybiniu mastu veikiančią gydytojų skatinimo dirbti rajonuose programą, todèl nenuostabu, kad geografinis gydytojų pasiskirstymas per pastaruosius penkiolika metu tapo dar netolygesnis - $1998 \mathrm{~m}$. miestuose dirbo 66,3 proc. visų Lietuvos gydytojų, tuo tarpu 2012 m. - 71,6 proc. ${ }^{14}$ Pastaruoju metu dažnai keliamas tik privalomo gydytojų rezidentų ịdarbinimo rajonų sveikatos priežiūros isstaigose klausimas, tačiau nediskutuojama apie skatinimo (pritraukimo) priemones, todèl tikslinga įvertinti kitų šalių patirtị, siekiant pagerinti geografinị gydytojų pasiskirstymą.

Šio straipsnio tikslas - sisteminès literatūros paieškos būdu atrinkti ir aprašyti pastaruosius dešimtmečius kitose pasaulio šalyse vykdytas programas, kurios buvo skirtos sumažinti netolygų geografini gydytojų pasiskirstymą.

\section{Tyrimo medžiaga ir metodika}

2009 m. Cochrane Collaboration paskelbtos sisteminès apžvalgos autoriai priejo prie išvados, jog nesant aukščiausios kokybės tyrimų, kuriuose būtų vertintas programų, skirtų sumažinti netolygų sveikatos priežiūros ir farmacijos specialistų geografinị pasiskirstymą, efektyvumas, negalima pagrịsti ar paneigti ịvairių rūšių programų naudingumo, sprendžiant šią problemą ${ }^{15}$. Todèl vykdydami sisteminę literatūros šaltinių paiešką nekèlème sau tikslo įvertinti programų efektyvumą.

Publikacijų paieška atlikta $2013 \mathrm{~m}$. birželio $5 \mathrm{~d}$., naudojant PubMed duomenų bazès paieškos sistemą. Paieškai pasitelkti šie reikšminių žodžių deriniai: „physicians AND recruitment AND retention“, „doctors AND recruitment AND retention“, „physicians AND retention AND rural“, „doctors AND retention AND rural“, "physicians AND retention AND remote“, „doctors AND retention AND remote“.

Literatūros šaltinių įtraukimo ir atmetimo kriterijai pateikiami 1 lentelèje.

1 lentelè. Literatūros šaltinių įtraukimo ir atmetimo kriterijai

\begin{tabular}{|l|l|l|}
\hline \multicolumn{1}{|c|}{ Kriterijus } & \multicolumn{1}{|c|}{ Itraukimo kriterijus } & \multicolumn{1}{c|}{ Atmetimo kriterijus } \\
\hline Laikotarpis & $20000101-20130531$ & $\begin{array}{l}\text { Anksčiau ar vèliau paskelbti } \\
\text { straipsniai }\end{array}$ \\
\hline Kalba & Anglų k. & Kita nei anglų k. \\
\hline Tyrimo vieta & Visos pasaulio šalys & - \\
\hline
\end{tabular}

12 Wilson, N. W., et al. A critical review of interventions to redress the inequitable distribution of healthcare professionals to rural and remote areas. Rural Remote Health. 2009, (2): 1060.

13 World Health Organisation. Increasing Access to Health Workers in Remote and Rural Locations through Improved Retention: Global Policy Recommendations. Geneva: WHO, 2010.

14 Supra note 7, p. 73-75.

15 Grobler, L., et al. Interventions for increasing the proportion of health professionals practising in rural and other underserved areas. Cochrane Database Syst Rev. 2009, (1): CD005314. 


\begin{tabular}{|l|l|l|}
\hline \multicolumn{1}{|c|}{ Kriterijus } & \multicolumn{1}{|c|}{ Ittraukimo kriterijus } & \multicolumn{1}{c|}{ Atmetimo kriterijus } \\
\hline Tiriamieji & Gydytojai & $\begin{array}{l}\text { Kiti sveikatos priežiūros ir far- } \\
\text { macijos specialistai }\end{array}$ \\
\hline Publikacijos tema & $\begin{array}{l}\text { Publikacijoje aprašoma gydy- } \\
\text { tojų pritraukimo ir išlaikymo } \\
\text { geografiškai nepatraukliose } \\
\text { vietovése programa }\end{array}$ & $\begin{array}{l}\text { Kita tema; publikacijoje neapra- } \\
\text { šoma programa }\end{array}$ \\
\hline Atvira prieiga & $\begin{array}{l}\text { Atvira prieiga prie visateksčio } \\
\text { straipsnio iš LSMU kompiuterių } \\
\text { tinklo }\end{array}$ & $\begin{array}{l}\text { Prieinama tik straipsnio san- } \\
\text { trauka }\end{array}$ \\
\hline Programos tipas & Veikianti programa & Teorine programa \\
\hline
\end{tabular}

Visi literatūros šaltiniai, kuriuose nebuvo aprašoma gydytojų pritraukimo ir išlaikymo geografiškai nepatraukliose vietovèse programa, buvo atmesti. Taip pat buvo atmesti tie šaltiniai, kuriuose buvo aprašomos kitiems sveikatos priežiūros ir farmacijos specialistams skirtos programos. Viena programa buvo atmesta, kadangi ji buvo skirta kariuomeneje tarnaujantiems gydytojams ${ }^{16}$. Dar viena (Keele universiteto) programa buvo atmesta, kadangi dar tik planuojama pradèti ją vykdyti ${ }^{17}$.

Sisteminès literatūros šaltinių paieškos ir atrankos schema pateikta 1 paveiksle.

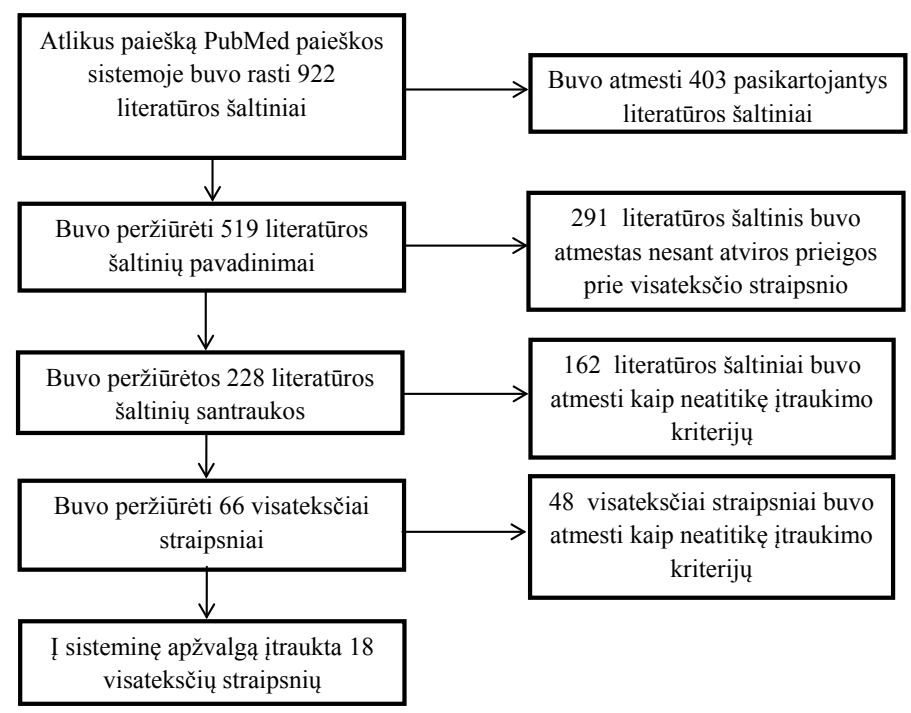

1 pav. Sisteminès literatūros šaltinių paieškos ir atrankos schema

Nustatytus kriterijus atitiko ir ị sisteminę apžvalgą buvo įtraukti 18 straipsnių, kuriuose aprašomos gydytojų pritraukimo ir išlaikymo geografiškai nepatraukliose vietovèse programos.

16 Holmes, S. L., el al. Military physician recruitment and retention: a survey of students at the Uniformed Services University of the Health Sciences. Mil Med. 2009,174(5): 529-534.

17 Deaville, J. A., et al. Perceptions of UK medical students on rural clinical placements. Rural Remote Health. 2009, 9(2): 1165. 


\section{Tyrimo rezultatai}

\subsection{Programu charakteristikos}

Visų ị sisteminę analizę ịtrauktų gydytojų pritraukimo ir išlaikymo geografiškai nepatraukliose vietovėse programų aprašymas (programos pavadinimas, tyrimo autoriai, vykdymo vieta ir laikotarpis, tikslas ir tikslinè grupè) pateikiamas 2 lenteleje.

2 lentelè. Gydytojų pritraukimo ir išlaikymo geografiškai nepatraukliose vietovėse programų charakteristikos

\begin{tabular}{|c|c|c|c|}
\hline $\begin{array}{c}\text { Pavadinimas, tyrimo } \\
\text { autoriai, metai }\end{array}$ & $\begin{array}{c}\text { Vieta, nuo kada } \\
\text { vykdoma }\end{array}$ & Tikslas & $\begin{array}{l}\text { Tikslinè grupè / } \\
\text { atrankos būdas }\end{array}$ \\
\hline $\begin{array}{l}\text { Jichi medicinos } \\
\text { universiteto (JMU) } \\
\text { gydytojų rengimo pro- } \\
\text { grama; M. Matsumoto } \\
\text { ir kt., } 2008 \text { m. }{ }^{18} \text {, } \\
\text { M. Matsumoto ir kt., } \\
2010 \text { m. }^{19}\end{array}$ & $\begin{array}{l}\text { Japonija, visa šalis, nuo } \\
1972 \mathrm{~m} \text {. }\end{array}$ & $\begin{array}{l}\text { Parengti rajonuose } \\
\text { dirbsiančius gydytojus } \\
\text { ir paskirstyti juos toly- } \\
\text { giai visoje šalyje }\end{array}$ & $\begin{array}{l}\text { Visi JMU medicinos } \\
\text { studentai }\end{array}$ \\
\hline $\begin{array}{l}\text { Australijos vyriausybės } \\
\text { stipendiju programa; D. } \\
\text { Wilkinson, } 2003 \mathrm{~m} \cdot{ }^{20}\end{array}$ & $\begin{array}{l}\text { Australija, visa šalis, } \\
\text { programos pradžia } \\
\text { nenurodyta }\end{array}$ & $\begin{array}{l}\text { Pritraukti ir } 6 \text { m. išlai- } \\
\text { kyti gydytojus geogra- } \\
\text { fiškai nepatraukliose } \\
\text { vietovèse }\end{array}$ & $\begin{array}{l}\text { Australijos pilietybę } \\
\text { (arba nuolatinio gyven- } \\
\text { tojo statusą) turintys } \\
\text { pirmo kurso medicinos } \\
\text { studijų studentai at- } \\
\text { rinkti konkurso būdu } \\
\text { (kasmet atrenkama } 100 \\
\text { studentų) }\end{array}$ \\
\hline $\begin{array}{l}\text { Naujojo Pietų Velso } \\
\text { sveikatos departamento } \\
\text { stipendiju progra- } \\
\text { ma; J. S. Dunbabin, } \\
2006 \mathrm{~m} .{ }^{21}\end{array}$ & $\begin{array}{l}\text { Australija, Naujojo } \\
\text { Pietų Velso valstija, nuo } \\
1989 \text { m. }\end{array}$ & $\begin{array}{l}\text { Sumažinti gydytojų } \\
\text { trūkumą rajonų ligoni- } \\
\text { nėse, pritraukti gydyto- } \\
\text { jus ị kaimo vietoves }\end{array}$ & $\begin{array}{l}\text { Australijos ir Naujosios } \\
\text { Zelandijos medicinos } \\
\text { studentai, atrinkti kon- } \\
\text { kurso būdu }\end{array}$ \\
\hline $\begin{array}{l}\text { "Friends of } \\
\text { Mosvold“ stipendijų } \\
\text { schema; A. J. Ross ir } \\
\text { kt., } 2007 \text { m. }{ }^{22}\end{array}$ & $\begin{array}{l}\text { Pietu Afrikos } \\
\text { Respublika, } \\
\text { Umkhanyakude rajo- } \\
\text { nas, nuo } 1998 \mathrm{~m} .\end{array}$ & $\begin{array}{l}\text { Padèti absolventams } \\
\text { ịsilieti ị rajono darbo } \\
\text { rinką }\end{array}$ & $\begin{array}{l}\text { Iš Umkhanyakude } \\
\text { rajono kilę studentai, } \\
\text { priimti ị trečios pako- } \\
\text { pos studijų programą ir } \\
\text { atrinkti vietos gyvento- } \\
\text { jų komiteto }\end{array}$ \\
\hline
\end{tabular}

18 Matsumoto, M.; Inoue, K.; Kajii, E. A contract-based training system for rural physicians: follow-up of Jichi Medical University graduates (1978-2006). J Rural Health. 2008, 24(4): 360-368.

19 Matsumoto, M., et al. Retention of physicians in rural Japan: concerted efforts of the government, prefectures, municipalities and medical schools. Rural Remote Health. 2010, 10(2): 1432

20 Wilkinson, D. Evidence-based rural workforce policy: an enduring challenge. Rural Remote Health. 2003, 3(1): 224.

21 Dunbabin, J. S.; McEwin, K.; Cameron, I. Postgraduate medical placements in rural areas: their impact on the rural medical workforce. Rural Remote Health. 2006, 6(2): 481.

22 Ross, A. J. Success of a scholarship scheme for rural students. S Afr Med. 2007, 97(11): 1087-1090. 


\begin{tabular}{|c|c|c|c|}
\hline $\begin{array}{l}\text { Pavadinimas, tyrimo } \\
\text { autoriai, metai }\end{array}$ & $\begin{array}{l}\text { Vieta, nuo kada } \\
\text { vykdoma }\end{array}$ & Tikslas & $\begin{array}{l}\text { Tikslinè grupè / } \\
\text { atrankos būdas }\end{array}$ \\
\hline $\begin{array}{l}\text { Bendruomenès me- } \\
\text { dicinos ar šeimos } \\
\text { medicinos rezidentūros } \\
\text { programa; K. Straume } \\
\text { ir kt., } 2010 \mathrm{~m} .^{23}\end{array}$ & $\begin{array}{l}\text { Norvegija, Finnmarko } \\
\text { apskritis, nuo } 1997 \text { m. }\end{array}$ & $\begin{array}{l}\text { Pritraukti ir išlaikyti } \\
\text { gydytojus geografiškai } \\
\text { nepatraukliose vieto- } \\
\text { vèse }\end{array}$ & $\begin{array}{l}\text { Vientisųjų medicinos } \\
\text { studijų programą (6 m.) } \\
\text { ir internatūrą ( } 1 \mathrm{~m} .) \\
\text { baigę absolventai, pa- } \\
\text { sirinkę bendruomenės } \\
\text { ar šeimos medicinos } \\
\text { rezidentūros studijų } \\
\text { programą }\end{array}$ \\
\hline $\begin{array}{l}\text { Minesotos universiteto } \\
\text { gydytojų pritraukimo i } \\
\text { geografiškai nepatrau- } \\
\text { klias vietoves progra- } \\
\text { ma; G. W. Haalas ir kt., } \\
2008 \mathrm{~m} .^{24}\end{array}$ & $\begin{array}{l}\text { JAV Minesotos valstija, } \\
\text { nuo } 1971 \mathrm{~m} \text {. }\end{array}$ & $\begin{array}{l}\text { Supažindinti trečia- } \\
\text { kursius su klinikinès } \\
\text { praktikos geografiškai } \\
\text { nepatraukliose vieto- } \\
\text { vėse ypatumais } 9 \text { mėn. } \\
\text { trukmès stažuotės } \\
\text { metu }\end{array}$ & $\begin{array}{l}\text { Trečio kurso medicinos } \\
\text { studentai, atrinkti kon- } \\
\text { kurso būdu }\end{array}$ \\
\hline $\begin{array}{l}\text { Džefersono me- } \\
\text { dicinos kolegijos } \\
\text { programa (PSAP); } \\
\text { H. K. Rabinowitz } \\
\text { ir kt., } 2001 \text { m. } .^{25} \text {; } \\
\text { H. K. Rabinowitz } \\
\text { ir kt., } 2012 \text { m. }{ }^{26} \text {; } \\
\text { H. K. Rabinowitz ir kt. } \\
2013 \text { m. }{ }^{27}\end{array}$ & $\begin{array}{l}\text { JAV Delavero ir } \\
\text { Pensilvanijos valstijos, } \\
\text { nuol974 m. }\end{array}$ & $\begin{array}{l}\text { Prièmimo ir studiju } \\
\text { programa, skirta } \\
\text { pritraukti ir išlaikyti } \\
\text { gydytojus kaimo vieto- } \\
\text { vese ir mažuose mies- } \\
\text { teliuose }\end{array}$ & $\begin{array}{l}\text { Studentai, užaugę } \\
\text { kaimo vietovėse ar } \\
\text { mažuose miesteliuose } \\
\text { ir ketinantys ten verstis } \\
\text { medicinos praktika, } \\
\text { atrinkti konkurso būdu }\end{array}$ \\
\hline $\begin{array}{l}\text { Nacionalinė gydytojų } \\
\text { iddarbinimo kaimo } \\
\text { vietovėse programa; } \\
\text { J. A. Leonardia ir kt., } \\
2012 \text { m. }{ }^{28}\end{array}$ & $\begin{array}{l}\text { Filipinai, visa šalis, nuo } \\
1993 \text { m. }\end{array}$ & $\begin{array}{l}\text { Pasiekti, kad kiekvie- } \\
\text { noje savivaldybeje po } \\
20 \mathrm{~m} \text {. dirbtų bent po } \\
\text { vieną gydytoją ( } 1992 \mathrm{~m} \text {. } \\
271 \text { savivaldybeje } \\
\text { nedirbo nè vienas gy- } \\
\text { dytojas) }\end{array}$ & $\begin{array}{l}\text { Sveikatos departamen- } \\
\text { to paskyrimas, tikslinè } \\
\text { grupè nenurodyta }\end{array}$ \\
\hline
\end{tabular}

23 Straume, K.; Søndenå, M. S.; Prydz, P. Postgraduate training at the ends of the earth - a way to retain physicians? Rural Remote Health. 2010, 10(2): 1356.

24 Halaas, G. W., et al. Recruitment and retention of rural physicians: outcomes from the rural physician associate program of Minnesota. J Rural Health. 2008 Fall;24(4): 345-352.

25 Rabinowitz, H. K., et al. Critical factors for designing programs to increase the supply and retention of rural primary care physicians. JAMA. 2001, 286(9): 1041-1048.

26 Rabinowitz, H. K., et al. Medical school rural programs: a comparison with international medical graduates in addressing state-level rural family physician and primary care supply. Acad Med. 2012, 87(4): 488-492.

27 Rabinowitz, H. K., et al. Retention of rural family physicians after 20-25 years: outcomes of a comprehensive medical school rural program. J Am Board Fam Med. 2013, 26(1): 24-27.

28 Leonardia, J. A., et al. Assessment of factors influencing retention in the Philippine National Rural Physician Deployment Program. BMC Health Serv Res. 2012, 12: 411. 


\begin{tabular}{|c|c|c|c|}
\hline $\begin{array}{c}\text { Pavadinimas, tyrimo } \\
\text { autoriai, metai }\end{array}$ & $\begin{array}{c}\begin{array}{c}\text { Vieta, nuo kada } \\
\text { vykdoma }\end{array} \\
\end{array}$ & Tikslas & $\begin{array}{l}\text { Tikslinè grupé / } \\
\text { atrankos būdas }\end{array}$ \\
\hline $\begin{array}{l}\text { Gydytojų skatinimo } \\
\text { dirbti kaimo vietovèse } \\
\text { programa; S. Pena ir } \\
\text { kt., } 2010 \mathrm{~m} .{ }^{29}\end{array}$ & $\begin{array}{l}\text { Čilè, visa šalis, nuo } \\
1963 \text { m. }\end{array}$ & $\begin{array}{l}\text { Pritraukti gydytojus } \\
\text { dirbti kaimiškose vie- } \\
\text { tovèse esančiuose pir- } \\
\text { minès SPI ir ligoninèse } \\
\text { (3-6 m. laikotarpiui) }\end{array}$ & $\begin{array}{l}\text { Medicinos absolven- } \\
\text { tai, atrinkti konkurso } \\
\text { būdu SAM paskelbus } \\
\text { apie laisvas paskyrimo } \\
\text { vietas }\end{array}$ \\
\hline $\begin{array}{l}\text { Nacionalinè kaimo } \\
\text { vietovių aprūpinimo } \\
\text { gydytojais programa; } \\
\text { T. Sundararaman ir kt., } \\
2011 \mathrm{~m} .{ }^{30}\end{array}$ & Indija, nuo 2005 m. & $\begin{array}{l}\text { Pritraukti ir 1-3 m. iš- } \\
\text { laikyti gydytojus kaimo } \\
\text { vietovėse }\end{array}$ & $\begin{array}{l}\text { Pageidaujantys gydyto- } \\
\text { jai, atrinkti konkurso } \\
\text { būdu }\end{array}$ \\
\hline $\begin{array}{l}\text { Nacionaline gydytojų } \\
\text { skatinimo dirbti kaimo } \\
\text { ir atokesnèse vietovèse } \\
\text { programa; A. Meliala ir } \\
\text { kt., } 2013 \mathrm{~m} .{ }^{31}\end{array}$ & $\begin{array}{l}\text { Indonezija, visa šalis, } \\
\text { nuo } 2006 \text { m. }\end{array}$ & $\begin{array}{l}\text { Pritraukti daugiau } \\
\text { gydytojų i kaimo ir } \\
\text { atokias vietoves }\end{array}$ & $\begin{array}{l}\text { Kaimo vietovèse pagei- } \\
\text { daujantys dirbti gydy- } \\
\text { tojai atrinkti konkurso } \\
\text { būdu }\end{array}$ \\
\hline $\begin{array}{l}\text { Sutarčių su gydytojais } \\
\text { programa; P. Zurn ir } \\
\text { kt., } 2010 \mathrm{~m} .{ }^{32}\end{array}$ & Senegalas, nuo $2006 \mathrm{~m}$. & $\begin{array}{l}\text { Pritraukti daugiau } \\
\text { gydytojų i geografiškai } \\
\text { nepatrauklias vietoves } \\
\text { (ypač pasienị) }\end{array}$ & $\begin{array}{l}\text { Pageidaujantys gydyto- } \\
\text { jai, atrinkti konkurso } \\
\text { būdu (laimèję negali } \\
\text { pasirinkti nei vietovès, } \\
\text { nei SPIt) }\end{array}$ \\
\hline $\begin{array}{l}\text { Marathono šeimos } \\
\text { praktikos programa; } \\
\text { E. Orrantia ir kt., } \\
2005 \mathrm{~m} .^{33}\end{array}$ & $\begin{array}{l}\text { Kanada, Ontarijo vals- } \\
\text { tijos Marathono mies- } \\
\text { telis, nuo } 1996 \mathrm{~m} .\end{array}$ & $\begin{array}{l}\text { Pritraukti ir išlaikyti } \\
\text { gydytojus Maratono } \\
\text { miestelio bendruome- } \\
\text { nèje }\end{array}$ & $\begin{array}{l}\text { Gydytojai, norintys } \\
\text { dirbti Marathono mies- } \\
\text { telyje, atrankos būdas } \\
\text { nenurodomas }\end{array}$ \\
\hline $\begin{array}{l}\text { Užsieniečiu gydytojų } \\
\text { ìdarbinimo (Conrad } 30 \\
\text { J-1 vizų) programa }{ }^{34,35}\end{array}$ & JAV, nuo 1995 m. & $\begin{array}{l}\text { Sumažinti gydytojų } \\
\text { trūkumą menkai gy- } \\
\text { dytojais aprūpintose } \\
\text { vietovèse }\end{array}$ & $\begin{array}{l}\text { Kiekviena valstija gali } \\
\text { geografiškai nepa- } \\
\text { traukliose vietovèse } \\
\text { ịdarbinti po } 30 \text { J-1 vizą } \\
\text { turinčių užsieniečių } \\
\text { gydytojų kasmet }\end{array}$ \\
\hline
\end{tabular}

SPİ - sveikatos priežiūros ịstaiga

Aštuoniolikoje straipsnių buvo aprašyta 14 programų. Džefersono medicinos kolegijos vietovių, kuriose trūksta gydytojų, aprūpinimo programa buvo aprašyta trijuose straips-

29 Peña, S., et al. The Chilean Rural Practitioner Programme: multidimensional strategy to attract and retain doctors in rural areas. Bull World Health Organ. 2010, 88(5): 37-378.

30 Sundararaman, T., supra note 6, p. 73-77.

31 Meliala, A.; Hort, K.; Trisnantoro, L. Addressing the unequal geographic distribution of specialist doctors in Indonesia: the role of the private sector and effectiveness of current regulations. Soc Sci Med. 2013, 82: 30-34.

32 Zurn, P., et al. How to recruit and retain health workers in underserved areas: the Senegalese experience. Bull World Health Organ. 2010,88(5): 386-389.

33 Orrantia, E. Marathon works. How to thrive in rural practice. Can Fam Physician. 2005, 51: 1217-1221.

34 Crouse, B. J.; Munson, R. L. The effect of the physician J-1 visa waiver on rural Wisconsin. Wisconsin Medical Journal. 2006, 105 (7): 16-20.

35 Kahn, T. R.; Hagopian, A.; Johnson, K. Retention of J-1 visa waiver program physicians in Washington State's health professional shortage areas. Acad Med. 2010, 85(4): 614-621. 
niuose, Jichi medicinos universiteto gydytojų rengimo programa ir užsieniečių gydytojų įdarbinimo (Conrad $30 \mathrm{~J}-1$ vizų) programa - dviejuose straipsniuose.

Ilgiausiai vykdoma programa buvo pradèta 1963 m. Čilèje, trumpiausiai - nuo $2006 \mathrm{~m}$. Senegale. Daugiausiai, po keturias programas, buvo vykdoma Šiaurès Amerikoje (trys JAV ir viena Kanadoje) ir Azijoje (Filipinuose, Indijoje, Indonezijoje ir Japonijoje), po dvi - Australijoje ir Afrikoje (Pietų Afrikos Respublikoje ir Senegale), po vieną Europoje (Norvegijoje) ir Pietų Amerikoje (Čilèje). Visos programos, remiantis PSO pasiūlyta klasifikacija, buvo suskirstytos it penkis tipus ir aprašomos toliau ${ }^{36}$.

\subsubsection{Medicinos studentų rengimo darbui geografiškai nepatraukliose vietovėse programos (su stipendija ir îsipareigojimais)}

Šių keturių programų skiriamasis bruožas - studentams skiriama stipendija (nuo 2 iki 6 metų), o mainais dalyviai įsipareigoja po studijų baigimo dirbti geografiškai nepatrauklios vietovès sveikatos priežiūros įstaigoje tam tikrą laikotarpi, svyruojantị nuo 2 iki 9 metų. I visas programas dalyviai atrenkami konkurso būdu.

Japonijoje 1972 m. buvo įkurtas Jichi medicinos universitetas, kuriame visi studijuojantys studentai tikslingai rengiami darbui tokiose vietovėse. Studentams paskiriama stipendija, apimanti stojimo mokestị, mokestị už mokslą, pragyvenimo išlaidas visus 6 studijų metus. Mainais jie įsipareigoja $9 \mathrm{~m}$. po studijų baigimo (3 podiplominių studijų metus ir 6 darbo prefektūroje metus) dirbti sveikatos priežiūros ịstaigoje tos prefektūros, iš kurios yra atvykę ${ }^{37},{ }^{38}$.

Pietų Afrikos Respublikoje vykdomos „Friends of Mosvold“ stipendijų schemos dalyviai taip pat įsipareigoja dirbti Umkhanyaku rajone - po vienerius metus už kiekvienus studijų metus, kai gavo stipendiją (padengiančią mokestị už mokslą, knygų, apgyvendinimo ir maitinimo išlaidas $)^{39}$.

Australijoje vykdomos dvi stipendijų programos - viena vykdoma nacionaliniu mastu ${ }^{40}$, o kita - Naujojo Pietų Velso valstijoje ${ }^{41}$. Tik Australijoje vykdomose programose nurodomas tikslus stipendijos dydis per metus, svyruojantis nuo 15 iki 25 tūkst. Australijos dolerių. Detaliausiai ịsipareigojimų ịvykdymo kontrolè aprašoma nacionalinėje Australijos programoje - jei programos dalyvis neįvykdo įsipareigojimo nepertraukiamai šešerius metus dirbti geografiškai nepatrauklios vietovès sveikatos priežiūros įstaigoje (ne mažiau kaip po 20 valandų per savaitę ir ne mažiau kaip 9 ménesius per metus), jis turi ne tik grąžinti visą stipendijos sumą (150 tūkst. Australijos dolerių), tačiau jam taip pat 12 metų uždraudžiama dirbti valstybineje Medicare sistemoje ${ }^{42}$. Pasakytina, jog šioje programoje numatyta galimybẻ sutrumpinti maksimalią ịsipareigojimo laikotarpio trukmę - jis gali būti trumpinamas, jei dalyvis pasirenka darbą ypač geografiškai atokioje vietovèje.

World Health Organisation, supra note 13, p. 35-341.

Matsumoto, M., supra note 18, p. 360-368.

Matsumoto, M., supra note 19, p. 1432.

Ross, A .J., supra note 22, p. 1087-1090.

Wilkinson, D., supra note 20, p. 224.

Dunbabin, J. S., supra note 21, p. 481.

Australian Government. Department of Health and Ageing. Medical Rural Bonded Scholarship

Scheme. Information Booklet for 2013. 


\subsubsection{Medicinos studentų rengimo darbui geografiškai nepatraukliose vietovèse programos (be stipendijos ir i̊sipareigojimų)}

Tyrime nagrinètos trys programos, kurių dalyviai studijų metu negauna stipendijų ar kitokių finansinių išmokų, tačiau taip pat neprisiima ir jokių ịsipareigojimų, pasibaigus programai.

Norvegijos Finnmarko apskrityje vykdoma profesinio palaikymo programa, skirta vientisųjų medicinos studijų programą ir internatūrą baigusiems absolventams, pasirinkusiems bendruomenès ar šeimos medicinos rezidentūros studijų programą. Studijų programa vykdoma sveikatos priežiūros įstaigose, kurios kai kuriais atvejais yra nutolusios nuo apskrities centro 500 kilometrų. Profesinio palaikymo programa nèra privaloma ir trunka dvejus (bendruomenés medicinos atveju) ar trejus metus (šeimos medicinos atveju, bendra abieju rezidentūros programų studijų trukmé - 5 metai). Grupés susitikimai vyksta vieną du kartus per ménesį (priklausomai nuo atstumo) po visą dieną. Išlaidos apmokamos iš valstybinio fondo. Dalyvio pageidavimu programa gali būti tęsiama ir vèliau - iki rezidentūros studiju programos pabaigos ${ }^{43}$.

Minesotos universitete vykdoma programa, skirta trečio kurso studentams, kuriems suteikiama galimybè atlikti devynių mėnesių trukmès klinikinę praktiką geografiškai nepatrauklios vietovès sveikatos priežiūros įstaigoje, vadovaujant pirminès sveikatos priežiūros gydytojui. Praktikos metu studentai ịvykdo iš anksto parengtą programą, šešis kartus susitinka su universiteto dèstytojais, gali dalintis savo patirtimi su kolegomis specialiame interneto forume ${ }^{44}$.

Džefersono medicinos kolegijos programos dalyviai atrenkami pagal du privalomus kriterijus: (a) jie turi būti užaugę kaimo vietovèse ar mažuose miesteliuose; ir (b) jie turi ketinti po studijų baigimo verstis medicinos praktika geografiškai nepatrauklioje vietoveje. Studentai mokosi pagal specialią studijų programą, kurioje daug dèmesio skiriama klinikinei praktikai rajonuose ar kaimo vietovèse. Šiems studentams paskiriamas vadovas iš Šeimos medicinos ir bendruomenès klinikos, kuriam dar padeda vyresnio kurso studentas. Taip pat programos dalyviams suteikiama pirmenybè renkantis šešiu savaičių trukmès klinikinès praktikos vietas ir sudaroma galimybe vasarą vykdyti mokamą tiriamąji darbą. Nors kontrolès mechanizmo nèra, laukiama, jog, baigę studijas, absolventai pasirinks šeimos ar kaimo medicinos rezidentūros studijų programą. Vis dèlto tyrimai rodo, jog šios programos dalyviai šeimos ar kaimo medicinos rezidentūros studijų programas pasirenka aštuonis kartus dažniau nei kiti studentai $\stackrel{45}{46},{ }^{47}$.

\subsubsection{I trumpalaikị (fiksuotos trukmès) gydytojų įdarbinimą orientuotos programos}

Tyrime nagrinètos penkios šio tipo programos, vykdomos Indijoje, Indonezijoje, Filipinuose, Senegale ir Čileje. Šiomis programomis siekiama pritraukti gydytojus ị geografiškai nepatrauklias vietoves fiksuotam laikotarpiui, svyruojančiam nuo 1 iki 6 metų.

\footnotetext{
Straume, K., supra note 23, p. 1356.

Halaas, G. W., supra note 24, p. 345-352.

Rabinowitz, H. K., supra note 25, p. 1041-1048.

Rabinowitz, H. K., supra note 26, p. 488-492.

Rabinowitz, H. K., supra note 27, p. 24-27.
} 
Pirmųjų dviejų programų dalyviams buvo siūlomos tik finansinès paskatos (didesnis nei miestuose dirbančių gydytojų darbo užmokestis ir / ar specialūs priedai) ir jomis buvo siekiama kompensuoti gydytojų trūkumą aiškiai apibrèžtą laikotarpi (iki 3 metų) ${ }^{48},{ }^{49}$.

Filipinuose vykdomos programos dalyviams, be didesnio atlyginimo ir socialinių garantijų, dar sudaroma galimybè lankyti profesinès kvalifikacijos kursus (du kartus per metus), o pasibaigus dvejų metų paskyrimo laikotarpiui - suteikiama pirmenybė stojant ị magistrantūros ar klinikinès rezidentūros studijų programų vietas ${ }^{50}$.

Programoje dalyvaujantys Senegalo gydytojai be didesnio atlyginimo dar yra įdarbinami kaip valstybès tarnautojai (ir jiems suteikiamos atitinkamos socialinės garantijos), taip pat skiriamas nemokamas apgyvendinimas ${ }^{51}$.

Kompleksiškiausia šio tipo programa vykdoma Čileje. Jos dalyviams (medicinos vientisųjų studijų programą baigusiems absolventams) ne tik skiriami didesni atlyginimai ir priedai (minimali sutarties trukmè - treji metai, maksimali - šešeri), tačiau ir suteikiamas būstas, skiriamos išmokos persikraustymui ir įsikūrimui, skiriamos papildomos 12 dienu atostogos, stažuotès, kvalifikacijos kèlimo kursai. Tačiau svarbiausiai - po trejų metų dalyvis igyja teisę studijuoti valstybès finansuojamoje rezidentūros studijų programos vietoje, tuo tarpu kitiems už šias studijas reikia mokèti apie 5000 JAV dolerių per metus. Atrankos i valstybès finansuojamas vietas metu visi programos dalyviai reitinguojami pagal iš anksto paskelbtus kriterijus: sutarties laikotarpio trukmė (10 balų), darbo sudettingumas (9 balai), darbas kaimiškųjų vietovių sveikatos postuose (8 balai), dar 3 balai skiriami tuo atveju, jei dalyvis buvo vienintelis gydytojas tame rajone. Papildomi 40 balų skiriami už bendruomenès ir sveikatos projektų inicijavimą ir vykdymą, vadybinių funkcijų atlikimą, sveikatos stiprinimo ir ugdymo veiklas ir paskelbtus mokslinius straipsnius ${ }^{52}$.

\subsubsection{Profesinio palaikymo programos}

Šio tipo bendruomeninè programa vykdoma Kanados Ontarijo valstijoje esančio Marathono miestelyje, kuriame dirba 9 šeimos gydytojai ir yra prisirašę 6500 gyventojų. Šie šeimos gydytojai yra susibūrę i grupę ir bendrai priima visus sprendimus. Atvykę gydytojai nepasirašo sutarčių ir neprisiima įsipareigojimų, o norėdami išvykti, turi ịspèti prieš mėnesị. Grupès susitikimai, kuriuose aptariami grupès ir medicinos praktikos klausimai, vyksta mažiausiai vieną kartą per mėnesį, taip pat veikia uždaras internetinis bendravimo forumas. Kiekvienų metų pradžioje gydytojas turi pasirinkti, kiek valandų per metus jis ketina dirbti (nèra minimalaus ar maksimalaus per savaitę dirbamų valandų skaičiaus), jam mokama už kiekvieną darbo valandą. Grupe bendru sutarimu sprendžia dèl atostogų ir profesinio tobulejimo kursų grafiko ir pavaduoja vieni kitus ${ }^{53}$.

\footnotetext{
Sundararaman, T., supra note 6, p. 73-77.

Meliala, A., supra note 31, p. 30-34.

Leonardia, J. A., supra note 28, p. 411.

Zurn, P., supra note 32, p. 386-389.

Peña, S., supra note 29, p. 371-378.

Orrantia, E., supra note 33, p. 1217-21.
} 


\subsubsection{Užsieniečių gydytojų įdarbinimo geografiškai nepatraukliose vietovėse programos}

Nors šios programos vykdomos ne vienoje pasaulio šalyje (Australijoje, Kanadoje, Afrikoje, Europoje), sisteminès literatūros atrankos kriterijus atitiko tik Jungtinėse Amerikos Valstijose vykdoma (Conrad 30 J-1 vizų) programa. Ši programa kiekvienai JAV valstijai suteikia galimybę kasmet geografiškai nepatraukliose vietovėse įdarbinti po 30 užsieniečių gydytojų trejų metų laikotarpiui, kuriam pasibaigus gydytojai ir jų šeimos nariai igyja teisę kreiptis dèl nuolatinio leidimo gyventi JAV. Gavę nuolatinio gyventojo statusą, gydytojai gali laisvai rinktis, kur toliau verstis medicinos praktika ${ }^{54},{ }^{55}$.

\subsection{Programų rezultatai}

Aprašydami programų rezultatus autoriai dažniausiai nurodè programoje per tam tikrą laikotarpị dalyvavusių dalyvių skaičių, ịsipareigojimus (jei tokie buvo taikomi) ịvykdžiusiųjų skaičių, gydytojų išlikimo geografiškai nepatrauklioje vietoveje rodiklius, pasibaigus sutarties laikotarpiui.

\subsubsection{Medicinos studentų rengimo darbui geografiškai nepatraukliose vietovèse programos (su stipendija ir ịsipareigojimais)}

Jichi medicinos universitetą Japonijoje 1978-2006 m. baige 2988 absolventai. Praejus 10-26 metams, tose pačiose vietovése dirbo 60-45 proc. absolventu $\mathrm{r}^{56},{ }^{57}$.

Pietų Afrikos Respublikoje „Friends of Mosvold“ stipendijų programą 1998-2007 m. baige 24 absolventai, 75 proc. tyrimo metu dirbo Umkhanyakude rajone ${ }^{58}$.

Australijoje vykdomos nacionalinės programos rezultatai nebuvo nurodyti, tačiau dèl griežtos ịsipareigojimų kontrolès ir nuobaudų tikètina, kad šią programą turètų baigti beveik visi dalyviai ${ }^{59}$. Naujojo Pietų Velso sveikatos departamento vykdomos programos stipendijos 1989-2004 m. buvo skirtos 180 studentų. 61,7 proc. jau buvo įvykdę savo įsipareigojimus, 25 proc. - tebevykdè, 11,1 proc. ịsipareigojimų neįvykdè (13 prieš pradèdami darbą geografiškai nepatrauklios vietovès sveikatos priežiūros įstaigoje, o septyni - šio darbo metu). Keturi studentai net nebaige medicinos studijų. $2004 \mathrm{~m}$. geografiškai nepatraukliose vietovèse tebedirbo 42 proc. ịvykdžiusių ịsipareigojimus ${ }^{60}$.

\footnotetext{
Crouse, B. J., supra note 34, p. 16-20.

Kahn, T. R., supra note 35, p. 614-21.

Matsumoto, M., supra note 18, p. 360-368.

Matsumoto, M., supra note 19, p. 1432.

Ross, A. J., supra note 22, p. 1087-1090.

Wilkinson, D., supra note 20, p. 224.

Dunbabin, J. S., supra note 21, p. 481.
} 
2.2.2. Medicinos studentų rengimo darbui geografiškai nepatraukliose vietovèse programos (be stipendijos ir ịsipareigojimų)

Norvegijos Finnmarko apskrities programoje 1995-2008 m. dalyvavo 40 studentų. Toje pačioje Finnmarko apskrities vietoveje praejjus penkeriems metams vis dar dirbo 65-67 proc. gydytojų ${ }^{61}$.

Minesotos universitete vykdomą programą nuo 1971 m. baigè 1175 absolventai, iš jų 901 gydytojas tyrimo metu vertèsi medicinos praktika, kiti tęsè studijas, o 15 buvo pasitraukę i kitas profesijas ar mirę. Geografiškai nepatraukliose vietovèse dirbo 49,7 proc. besivertusiųju medicinos praktika ${ }^{62}$.

Džefersono medicinos kolegijos programą 1978-1986 m. baigè 148 studentai. $2011 \mathrm{~m}$. 70,3 proc. šios programos absolventų vis dar vertesi medicinos praktika toje pačioje paskyrimo vietoveje (lyginant su 46,2 proc. nedalyvavusiųjų šioje programoje) ${ }^{63}$.

\subsubsection{I trumpalaikị (fiksuotos trukmès) gydytojų ịdarbinimą orientuotos programos}

Indijoje per dvejus programos igyvendinimo metus buvo įdarbinti 9172 gydytojai. Tyrime nevertintas jų išlikimas geografiškai nepatrauklioje vietovejje, pasibaigus sutarties laikotarpiui ${ }^{64}$.

Tyrime, kuriame analizuota Indonezijoje vykdoma programa, nei įdarbintų gydytoju skaičius, nei jų išlikimo rodikliai nepateikiami, tačiau teigiama, jog, nepaisant priemonių, geografinis gydytojų pasiskirstymas išliko labai netolygus ${ }^{65}$.

1993-2011 m. Filipinuose vykdytoje programoje dalyvavo 452 gydytojai. Pasibaigus sutarčiai, savo paskyrimo vietose pasiliko 18 proc. gydytojų ${ }^{66}$.

Senegalo sveikatos apsaugos ministerija 2006-2008 m. sudare sutartis su 59 gydytojais, apie jų išlikimą dirbti geografiškai nepatraukliose vietovése pasibaigus sutarčiai nepranešama ${ }^{67}$.

Čileje vykdomoje programoje 2001-2009 m. dalyvavo 1209 dalyviai. Beveik visi dalyviai dirbo privalomą trejų metų trukmès sutarties laikotarpị; maksimalų šešerių metų laikotarpi dirbo 58 proc. dalyvių ${ }^{68}$.

\subsubsection{Profesinio palaikymo programos}

Kanados Ontarijo valstijoje esančio Marathono miestelio šeimos gydytoju grupejje per 9 metus dirbo 16 gydytojų. Tyrimo metu iš jų dar tebedirbo devyni gydytojai ${ }^{69}$.

Straume, K., supra note 23, p. 1356.

Halaas, G. W., supra note 24, p. 345-352.

Rabinowitz, H. K., supra note 27, p. 24-27.

Sundararaman, T., supra note 6, p.73-77.

Meliala, A., supra note 31, p. 30-34.

Leonardia, J. A., supra note 28, p. 411.

Zurn, P., supra note 32, p. 386-389.

Peña, S., supra note 29, p. 371-378.

Orrantia, E., supra note 33, p. 1217-1221. 


\subsubsection{Užsieniečių gydytojų įdarbinimo geografiškai nepatraukliose vietovėse programos}

Conrad $30 \mathrm{~J}-1$ vizų programos rezultatai dviejose valstijose buvo labai skirtingi. Viskonsino valstijoje 1996-2002 m. buvo įdarbinti 145 gydytojai, tačiau 30 proc. neįvykdè sutarties. Iš įvykdžiusiųjų praejjus trejiems metams darbą tęsẻ 71,7 proc. $^{70}$ Tuo tarpu Vašingtono valstijoje 1995-2003 m. buvo įdarbinti 155 gydytojai, o praejjus trejiems metams darbą paskyrimo vietoveje tebetęsè 26 proc. $^{71}$

\section{Rezultatų aptarimas}

PSO rekomenduoja, jog rengdami nacionalines ar regionines programas sveikatos politikai turètų atsižvelgti į: (a) nacionalinius prioritetus ir sveikatos priežiūros specialistų bei geografiškai nepatrauklių vietovių gyventojų lūkesčius; (b) programų priimtinumą kuo platesniam suinteresuotųjų šalių skaičiui; (c) finansines galimybes; (d) kitose šalyse vykdomų programų efektyvumą; (e) laukiamo programų poveikio vertinimą. Ši organizacija taip pat rekomenduoja, kad šios programos turètų apimti kompleksines poveikio priemones: (a) sveikatos priežiūros ir farmacijos specialistų rengimo ir reguliacines priemones; (b) finansinio skatinimo priemones; (c) asmeninio, profesinio ir socialinio palaikymo priemones ${ }^{72}$. Tuo tarpu mūsų darbe nustateme tik vieną programą, kurioje buvo taikomos kompleksinès priemonès $^{73}$.

Programos, kuriose taikomos tik finansinès paskatos, dažniausiai pasiteisina, pritraukiant gydytojus i geografiškai nepatrauklias vietoves ir išlaikant juos ten trumpą laikotarpi (2-6 m. $)^{74},{ }^{75},{ }^{76},{ }^{77},{ }^{78}$, tačiau neprisideda prie ilgalaikio problemos sprendimo, kadangi geresnès ekonominès, socialinès ir kitos gyvenimo ir darbo miestuose sąlygos skatina specialistus sugrįžti į miestus ${ }^{79},{ }^{80}$.

Kai kurios šalys netolygaus geografinio pasiskirstymo problemą sprendžia nepatraukliose vietovèse esančiose sveikatos priežiūros ịstaigose įdarbindamos iš kitų šalių atvykusius gydytojus, tačiau tai taip pat nèra ilgalaikis sprendimas, kadangi jis veiksmingas iki sutarties galiojimo pabaigos (pasakytina, kad, net ir sudarę sutartis, ne visi dalyviai ịvykdo prisiimtus issipareigojimus), o vèlesnio išlikimo rodikliai dviejuose tyrimuose labai skyrèsi ${ }^{81},{ }^{82}$.

\footnotetext{
Crouse, B. J., supra note 34, p. 16-20.

Kahn, T. R., supra note 35, p. 614-621.

World Health Organisation, supra note 13, p. 35-41.

Peña, S., supra note 29, p. 371-378.

Sundararaman, T., supra note 6, p.73-77.

Meliala, A., supra note 31, p. 30-34.

Leonardia, J. A., supra note 28, p. 411.

Zurn, P., supra note 32, p. 386-389.

Peña S., supra note 29, p. 371-378.
}

79 Sempowski, I. P. Effectiveness of financial incentives in exchange for rural and underserviced area return-of-service commitments: systematic review of the literature. Canadian Journal of Rural Medicine. 2004, 9: 82-88.

80 Barnighausen,T.; Bloom, D. Financial incentives for return of service in underserved areas: a systematic review. BMC Health Services Research. 2009, 9: 86.

81 Crouse, B. J., supra note 34, p. 16-20.

82 Kahn, T. R., supra note 35, p. 614-621. 
Medicinos studentų rengimo darbui geografiškai nepatraukliose vietovėse programų (tiek su stipendija ir ịsipareigojimais, tiek be jų) rezultatai buvo geresni nei tik finansines paskatas ar ị užsienio gydytojus orientuotų programų rezultatai ir dažnas dalyvis tęsdavo medicinos praktiką toje pačioje vietovejje ilgesnị laiką. Nors šios programos nepadeda greitai išspręsti gydytojų trūkumo problemos, tačiau jos labai naudingos ilguoju laikotarpiu ${ }^{83,84,85,86,87,88,89}$.

Atrankos kriterijų neatitiko nè viena privalomo gydytojų ịdarbinimo kaimo vietovèse programa, tačiau sisteminès apžvalgos, kurioje buvo vertintas tokių programų efektyvumas, autorių teigimu, šios programos labai dažnai sukelia medikų bendruomenès nepasitenkinimą, todèl jas būtina kruopščiai planuoti, pagrịsti jų būtinybę, užtikrinti skaidrumą ir būtinai susieti su kompleksinėmis skatinimo ir palaikymo priemonėmis ${ }^{90}$.

\section{Išvados}

1. Nepaisant to, jog daugiau nei pusę amžiaus ịvairiose pasaulio šalyse vykdomos nacionalinès, regioninès ar bendruomeninès programos, skatinančios gydytojus ar medicinos studentus vykti dirbti ị geografiškai nepatrauklias vietoves, tik nedidele jų dalis aprašyta mokslinejje literatūroje, jau nekalbant apie tai, jog iki šiol nèra atlikti aukštos kokybès šių programų efektyvumo tyrimai, kuriais remiantis būtų galima įvardinti labiausiai pasiteisinusias (ar priešingai - nepasiteisinusias) programas.

2. Remiantis sisteminès literatūros apžvalgos rezultatais galima teigti, jog prie ilgalaikio netolygaus geografinio gydytojų pasiskirstymo problemos sprendimo labiau prisideda i medicinos studentų rengimą darbui geografiškai nepatraukliose vietovèse orientuotos programos, tuo tarpu užsieniečių ịdarbinimo programos ar vien tik finansinėmis paskatomis grịstos programos, nors ir padeda greitai išspręsti šią problemą, yra tik trumpalaikiai sprendimai. Todèl Lietuvoje rengiant valstybiniu mastu veikiančią gydytojų skatinimo dirbti rajonuose programą būtina atlikti ne tik mokslinès literatūros apžvalgą, tačiau ir išnagrinèti tokio pobūdžio literatūroje neskelbtus kitose šalyse veikiančių programų aprašus. Taip pat būtinas įvairių suinteresuotųjų šalių dalyvavimas bei detali analizė ir būsimos programos poveikio (tiek teigiamo, tiek neigiamo) vertinimas.

\section{Literatūra}

1. Australian Government. Department of Health and Ageing. Medical Rural Bonded Scholarship Scheme. Information Booklet for 2013.

2. Barnighausen, T.; Bloom, D. Financial incentives for return of service in underserved areas: a systematic review. BMC Health Services Research. 2009, 9: 86.

3. Blumenthal, D. Geographic imbalances of physician supply: an international comparison. Journal of Rural Health. 1994, 10(2): 109-118.

\footnotetext{
Straume, K., supra note 23, p. 1356.

Halaas, G. W., supra note 24, p. 345-352.

Rabinowitz, H. K., supra note 27, p. 24-27.

Matsumoto, M., supra note 18, p. 360-368.

Matsumoto, M., supra note 19, p. 1432.

Ross, A. J., supra note 22, p. 1087-1090.

Dunbabin, J. S., supra note 21, p. 481.
}

90 Frehywot, S., et al. Compulsory service programmes for recruiting health workers in remote and rural areas: do they work? Bull World Health Organ. 201088(5): 364-370. 
4. Buykx, P., et al. Systematic review of effective retention incentives for health workers in rural and remote areas: towardsevidence-based policy. Aust J. Rural Health. 2010, 18(3): 102-109.

5. Crouse, B. J.; Munson, R. L. The effect of the physician J-1 visa waiver on rural Wisconsin. Wisconsin Medical Journal. 2006, 105(7): 16-20.

6. Deaville, J. A., et al. Perceptions of UK medical students on rural clinical placements. Rural Remote Health. 2009, 9(2): 1165.

7. Dumont, J. C., et al. International mobility of health professionals and health workforce management in Canada: myths and realities. OECD Health working paper no 40. Paris: OECD, 2008.

8. Dunbabin, J. S.; McEwin, K.; Cameron, I. Postgraduate medical placements in rural areas: their impact on the rural medical workforce. Rural Remote Health. 2006, 6(2): 481.

9. Dussault, G.; Franceschini, M. Not enough there, too many here: understanding geographical imbalances in the distribution of the health workforce. Human Resources for Health. 2006, 4: 12.

10. Gupta, N., et al. Uses of population census data for monitoring geographical imbalance in the health workforce: snapshots from three developing countries. Int J Equity Health. 2003, 2(1): 11 .

11. Frehywot, S., et al. Compulsory service programmes for recruiting health workers in remote and rural areas: do they work? Bull World Health Organ. 2010, 88(5): 364-370.

12. Grobler, L., et al. Interventions for increasing the proportion of health professionals practising in rural and other underserved areas. Cochrane Database Syst Rev. 2009, (1): CD005314.

13. Halaas, G. W., et al. Recruitment and retention of rural physicians: outcomes from the rural physician associate program of Minnesota. J Rural Health. 2008, 24(4): 345-352.

14. Lietuvos gyventoju sveikata ir sveikatos priežiūros ịstaigu veikla $2012 \mathrm{~m}$. (išankstiniai duomenys). Vilnius: Higienos instituto Sveikatos informacijos centras, 2013.

15. Holmes, S. L., et al. Military physician recruitment and retention: a survey of students at the Uniformed Services University of the Health Sciences. Mil Med. 2009, 174(5): 529-534.

16. Humphreys, J.; Solarsh, G. At-rist populations: rural. Heggenhougen HK, ed. The International Encyclopedia of Public Health. London: Elsevier, 2008: 242-253.

17. Kahn, T. R.; Hagopian, A.; Johnson, K. Retention of J-1 visa waiver program physicians in Washington State's health professional shortage areas. Acad Med. 2010, 85(4): 614-621.

18. Leonardia, J. A., et al. Assessment of factors influencing retention in the Philippine National Rural Physician Deployment Program. BMC Health Serv Res. 2012, 12: 411.

19. Lietuvos statistikos departamentas. Oficialiosios statistikos portalas [žiūrèta 2013-0424]. <http://osp.stat.gov.lt>.

20. Matsumoto, M., et al. Retention of physicians in rural Japan: concerted efforts of the government, prefectures, municipalities and medical schools. Rural Remote Health. 2010, 10(2): 1432 .

21. Matsumoto, M.; Inoue, K.; Kajii, E. A contract-based training system for rural physicians: follow-up of Jichi Medical University graduates (1978-2006). J Rural Health. 2008, 24(4): 360-368.

22. Meliala, A.; Hort, K.; Trisnantoro, L. Addressing the unequal geographic distribution of specialist doctors in Indonesia: the role of the private sector and effectiveness of current regulations. Soc Sci Med. 2013, 82: 30-34. 
23. Orrantia, E. Marathon works. How to thrive in rural practice. Can Fam Physician. 2005, 51: 1217-1221.

24. Peña, S., et al. The Chilean Rural Practitioner Programme: multidimensional strategy to attract and retain doctors in rural areas. Bull World Health Organ. 2010, 88(5): 371-378.

25. Rabinowitz, H. K., et al. Critical factors for designing programs to increase the supply and retention of rural primary care physicians. JAMA. 2001, 286(9):1041-1048.

26. Rabinowitz, H. K., et al. Medical school rural programs: a comparison with international medical graduates in addressing state-level rural family physician and primary care supply. Acad Med. 2012, 87(4): 488-492.

27. Rabinowitz, H. K., et al. Retention of rural family physicians after 20-25 years: outcomes of a comprehensive medical school rural program. J Am Board Fam Med. 2013, 26(1): 24-27.

28. Ross, A. J. Success of a scholarship scheme for rural students. S Afr Med J. 2007, 97(11): 1087-1090.

29. Sempowski, I. P. Effectiveness of financial incentives in exchange for rural and underserviced area return-of-service commitments: systematic review of the literature. Canadian Journal of Rural Medicine. 2004, 9: 82-88.

30. Straume, K.; Søndenå, M. S.; Prydz, P. Postgraduate training at the ends of the earth - a way to retain physicians? Rural Remote Health. 2010, 10(2): 1356.

31. Sundararaman, T.; Gupta, G. Indian approaches to retaining skilled health workers in rural areas. Bull World Health Organ. 2011, 89(1): 73-77.

32. Wibulpolprasert, S.; Pengpaibon, P. Integrated strategies to tackle the inequitable distribution of doctors in Thailand: four decades of experience. Hum Resour Health. 2003, 1(1): 12 .

33. Wilkinson, D. Evidence-based rural workforce policy: an enduring challenge. Rural Remote Health. 2003, 3(1): 224.

34. Wilson, N. W., et al. A critical review of interventions to redress the inequitable distribution of healthcare professionals to rural and remote areas. Rural Remote Health. 2009, 9(2): 1060.

35. World Health Organisation. Increasing Access to Health Workers in Remote and Rural Locations through Improved Retention: Global Policy Recommendations. Geneva: WHO, 2010.

36. World Health Organisation. World Health Report 2006: Working together for health. 2006.

37. Zurn, P., et al. How to recruit and retain health workers in underserved areas: the Senegalese experience. Bull World Health Organ. 2010, 88(5): 386-389.

\title{
Inequitable Geographic Distribution of Physicians: Systematic Review of International Experience
}

\author{
Liudvika Starkienè \\ Department of Preventive Medicine, \\ Lithuanian University of Health Sciences, Lithuania
}

\section{Summary}

Background. According to the World Health Organization, approximately one half of the global population lives in rural areas, but these are served by less than a quarter of total physician 
workforce. This is a global problem that affects almost all countries: some countries are affected to a higher degree and some to a lower degree. Over the last fifty years, various attempts to solve this problem have been observed in different parts of the world.

Material and methods. The author carried out a systematic literature search of PubMed for studies describing intervention programmes aimed at improvement of recruitment and retention of physicians to geographically remote or rural areas. The following inclusion criterion was used: full-text articles, describing programmes aimed at physicians and published in English in 20002013. In the initial search, 922 articles were identified, 856 of which were excluded as duplicates or based on their titles or abstracts. Full-text reviews of the remaining 66 articles were conducted. Eighteen articles, which described 14 programmes, were included in the final review.

Results. Considering the reviewed 14 programmes, the earliest programme was started in Chille in 1963 and the latest - in Senegal in 2006. Four programmes were implemented in North America (three in the USA and one in Canada) and Asia (Philippines, India, Indonesia and Japan), two in Australia (nationally and in New South Wales) and Africa (South Africa and Senegal), one in Europe (Norway) and South America (Chille). The following types of programmes were analysed: educational programmes, which train medical students for rural and remote areas (with scholarships and obligations), educational programmes, which train medical students for rural and remote areas (without scholarships and obligations), short-term oriented programmes, professional support programmes and programmes aimed at bringing international medical graduates to rural and remote areas. Programmes, which were aimed at resolving physician shortage in the short-term, usually included financial incentives and some of them included other benefits (social benefits, free housing, etc.). These programmes were successful in retaining physicians for duration of contract (2-6 years), and so were international medical graduates-oriented programmes. Educational programmes, which train medical students for rural and remote areas, showed some promise, as their results were better compared to other programmes. These programmes contribute to solving the issue in the long-term.

Conclusion. Even though different countries have implemented different intervention programmes to address geographic maldistribution of physicians, the design of studies, which were included in this systematic review, did not allow to confirm whether any of the reviewed programmes were effective or not. Rigorous studies are needed to evaluate the true effect of these programmes to increase the number of physicians working in remote and rural areas.

Keywords: physicians, geographic maldistribution, recruitment and retention programmes, health policy.

Liudvika Starkienė, Lietuvos sveikatos mokslų universiteto Medicinos akademijos Visuomenès sveikatos fakulteto Profilaktinès medicinos katedros docentè, mokslų daktarè. Mokslinių interesų sritys: sveikatos priežiūros žmogiškųjų išteklių pasiūlos ir poreikio analizė ir prognozès, sveikatos politika, specialistų migracija, specialistų rengimas, pasitraukimas iš profesijos, netolygus geografinis pasiskirstymas.

Liudvika Starkienė, PhD, Lithuanian University of Health Sciences, Medical Academy, Faculty of Public Health, Department of Preventive Medicine, Associated Professor. Research interests: supply and requirement of human resources for health and their future projections, training and migration issues, drop out from profession, geographic maldistribution, health policy. 